\title{
POSTCOLONIALISM IN AFRICA BASED ON COLONIALISM ANALYSIS IN CHINUA ACHEBE'S THINGS FALL APART
}

\author{
POSTKOLONIALISME DI AFRIKA BERDASARKAN ANALISIS \\ KOLONIALISME DALAM THINGS FALL APART KARYA CHINUA \\ ACHEBE
}

\author{
Adi Yusuf \\ Universitas Pesantren Tinggi Darul Ulum Jombang \\ adiyusuf@fbs.unipdu.ac.id
}

\begin{abstract}
One of the interesting things in the study of literary works is to explore the representation of a literary work itself to the culture of real life. More specifically, when it is related to the history - in this case, the condition of precolonial, colonial, and postcolonial times. This article discusses postcolonialism analysis on Things fall Apart by Achebe. The method used in this study is descriptive qualitative. It is found that the novel represents "precolonial tribal" life in Africa: earning a living by farming land and keeping the cattle, diverse cultural backgrounds including belief of traditional religion. Then, the things lost as a result of colonial contact are "religious practice and government". Then, Colonizers' strategies in indoctrinating the native population to their way of thinking include building a school, convincing the society of the importance of education for the future generation, and building the court for judgement and protection. There are some reasons that make colonizers' successful, they are: they make mutual benefit of trading, use a soft way to spread the belief, and use an innovative way to link the religion and the education. Furthermore, after colonialism, Africa experiences mixed reaction of religious practice, education becomes the key to get success in career, two ways of healers: the traditional African healers i.e. "using ritual and herbal remedies and modern cures, hospital, and the establishment of Courts of Justice and Human Rights".
\end{abstract}

Keywords: precolonial life, positive effects, negative effects, postcolonialism.

\begin{abstract}
Abstrak
Salah satu hal yang menarik dalam studi karya sastra ialah mengeksplorasi representasi karya sastra itu sendiri dengan budaya kehidupan nyata, lebih khusus lagi, ketika dikaitkan dengan sejarah - dalam hal ini, kondisi pada saat pra-kolonial, kolonial, dan postkolonial. Artikel ini bertujuan untuk membahas tentang postkolonialisme pada novel Things Fall Apart oleh Achebe. Metode yang digunakan dalam studi ini adalah deskriptif qualitative. Hasil penelitian ini menunjukkan bahwa novel tersebut merepresentasikan kehidupan suku "precolonial di Afrika": mencari nafkah dengan bertani dan memelihara binatang ternak, latar belakang budaya yang beragam termasuk keyakinan agama tradisional. Hal-hal yang hilang/ negatif akibat dari kontak kolonial pada penduduk asli yaitu "praktik agama dan pemerintahan". Ada tiga strategi yang dilakukan oleh penjajah dalam mengindoktrinir penduduk asli terhadap cara berpikir mereka antara lain: "membangun sebuah sekolah, meyakinkan masyarakat akan pentingnya pendidikan bagi generasi masa depan, dan membangun pengadilan untuk mencari keadilan dan perlindungan".
\end{abstract}


Penjajah sukses karena mereka mengadakan "perdagangan yang saling menguntungkan, menggunakan cara yang lembut untuk menyebarkan keyakinan, dan menggunakan cara yang inovatif untuk menghubungkan antara agama dan pendidikan". Beberapa efek dari kolonialisme tersebut antara lain: (1) terdapat beberapa agama di Afrika, (2) pendidikan menjadi kunci untuk mendapatkan kesuksesan dalam karir, (3) ada dua cara penyembuhan: (1.penyembuhan tradisional Afrika yaitu menggunakan ritual dan herbal, dan 2. obat modern, rumah sakit), dan (4) pendirian Pengadilan Hukum dan Hak Asasi Manusia.

Kata Kunci: kehidupan prekolonial, efek negatif, efek positif, postkolonial

\section{INTRODUCTION}

One of the interesting things in the study of literary works is to "explore the representation of a literary work itself to the culture of real life". More specifically, when it is related to the history - in this case, the condition of "precolonial, colonial, and postcolonial times". Ratna (2005: p.240) defines postcolonialism theory as 'a critical theory which tries to explore negative effects caused by colonialism'. In addition, 'the study of postcolonialism is not only related to the past events, but also 'the colonizers' and 'the colonized people' in the third world. So, in the study of postcolonialism, it is necessary to see the representation of history, and the related things of the events to the third world, postcolonial' (Endraswara, 2003: p.178).

During the precolonial and colonial times, there must be "two effects", i.e. the positive effects and the negative effects. Endraswara (2003: p.180) explains that the study of postcolonialism may reflect two things opposite to colonial period. The first, there is a 'simbiosis' between 'the colonizers' and 'the colonized people'. Good cooperation of both of them frequently creates a new life. In this case, there is no criticism between them since all behavior is covered by 'understanding'. The second, there must be an action of “insulting each other", disagreement, repression, and ambivalent relationship.

From the above discussion, it is clear that the study of postcolonialism tends to compare two fortification, the colonizers and the colonized people. The study can only be understood by the historical events. Therefore, this paper would like discuss the unique things: the novel's representation of prerecolonial tribal life in Africa, what is lost as a result of colonial contact, what are the colonizers' strategies in indoctrining the native population to their way of thinking, why the colonizers are so successful, and the condition of Africa since independence. 


\section{RESEARCH METHOD}

The method used in this study is a descriptive qualitative. The aim of this study is to describe postcolonialism in Africa based on colonialism analysis in Things Fall Apart written by Chinua Achebe. The data of this study are in the form of quotation marks. The approach of this study is library research. To get the information related to the topic or problem discussesed, it uses books, encyclopedia, and other sources.

\section{DISCUSSION}

\section{A. The Novel's Representation of "Precolonial Tribal Life in Africa"}

Pre-colonial African societies, indeed, had varied nature. Most Africans live in "rural areas and make a living by farming land and keeping the cattle”. It can be seen in the novel:

'He was a wealthy farmer and had two barns full of yams'(Achebe:5), "During the planting season Okonkwo worked daily on his farms from cockcrow until the chickens went to roost'.... "At the opposite end of the compound was a shed for the goats, and each wife built a small attachment to her hut for the hens" (Achebe:9).

This is also written in the book of The World Book of Encyclopaedia that approximately half the people in "northern Africa live in rural areas". Most of them raise "livestock or grow crops on small plots land". They do much of the work manually or with the help of animals'(Anderson et. al., 2007: p.107) besides, "In general, sub-Saharan Africas follow their traditional ways and observe the "customs of their ancestors". Most Africans live in "rural areas and make a living by farming land".(Anderson et. al., 2007: pp.109-110).

Next, Africa has many diverse cultural backgrounds. The ethnic has its own belief of traditional religion. For example, the ceremonial process using 'sacrifice' things. The novel says "Obiako has always been a strange one," said Nwakibie. "I have heard that many years ago, when his father had not been dead very long, he had gone to consult the Oracle. The Oracle said to him, 'Your dead father wants you to sacrifice a goat to him.' (p.14).

the other part tells:

Before it was dusk Ezeani, who was the priest of the earth goddess, Ani, called on Okonkwo in his obi. Okonkwo brought out kola nut and placed it before the priest, "Take away your kola nut. I shall not eat in the house of a man who 
has no respect for our gods and ancestors." .' "Listen to me," he said when Okonkwo had spoken. "You are not a stranger in Umuofia. You know as well as I do that our forefathers ordained that before we plant any crops in the earth we should observe a week in which a man does not say a harsh word to his neighbour. We live in peace with our fellows to honour our great goddess of the earth without whose blessing our crops will not grow.. (pp.20-21).

In addition it is shown in the conversation between Mr. Brown and Akunna on their belief. Akunna said "We make sacrifices to the little gods, but when they fail and there is no one else to turn to we go to Chukwu "(p.124). In the cases of ceremonies and traditional religion practices, they are also shown in the book of The World Book of Encyclopaedia "Millions of Africans practice local traditional religions. There are hundreds of African traditional religions because each ethnic group has its own set of beliefs and practises. In general, however, local religions have many features in common.

".. African traditional religions all recognize the existence of a supreme god. However, most of the African traditional religions emphasize that people should seek help by appealing to lesser gods or to the spirits of dead ancestors. People pray or offer sacrifices to the gods or the spirits to gain such things as good health or fertile land" (Anderson et. al., 2007: p.106).

In the process of funeral, the African plays music using instruments which are made from "metal" and things surroundings their environment and drink palm-wine. This is stated on page 6,7 , and 12 in the novel as follows:

"Okonkwo had just blown out the palm-oil lamp and stretched himself on his bamboo bed when he heard the ogene of the town crier piercing the still night air. Gome, gome, gome, gome, boomed the hollow metal. Then the crier gave his message, and at the end of it beat his instrument again" (p.6)

"On great occasions such as the funeral of a village celebrity he drank his palm-wine from his first human head." (p.7)

"We pray for life, children, a good harvest and happiness". "You will have what is good for you and I will have what is good for me." Let the kite perch and let the eagle perch too. If one says no to the other, let his wing break."

After the kola nut had been eaten Okonkwo brought his palm-wine from the corner of the hut where it had been placed and stood it in the centre of the group. He addressed Nwakibie, calling him "Our father."'Nna ayi," he said. "I have brought you this little kola. (p.12).

This kind of tribal life can also be found in The World Book of Encyclopaedia "Male artists traditionally work with hard materials: wood, metals and bone. They also produces ceremonial items, including masks, figures, and musical instruments. materials 
used are dependent on what is available in the environment such as "stone, bone, clay, leather, and fiber". Woodcarving is the most common in west and central africa (p.115). Besides, dance and music often accompany the display of ceremonial art objects in public, such as a funeral or the installation of a chief”' (Anderson et al., 2007: p.116).

Then, In the case of marriage, there was a tradition, namely 'poliginy' (a man having more than one wives), and family, the women stayed at home "to care their family". It is shown in the novel that Nwakibi has nine wives "There was a wealthy man in Okonkwo's village who had three huge barns, nine wives and thirty children"(p.12). and Okonkwo's second wife had merely cut a few leaves off it to wrap some food"(p.26). This is also dicussed in The World Book of Encyclopaedia "at one time, Islamic traditions regulated marriage practices and family life throughout the northern Africa. These tradition 'poliginy' - the right of a man to have more than one wife. They also required a bride's family to "give a dowry" of household, frequently "goods or money to the bridgeroom."(p.107) and "traditionally women in northern Africa remained at home to care their families. Many older women and those who live in rural regions still follow this tradition" (Anderson, et al., 2007: p.109).

From the discussion above, It can be said that the novel Things Fall Apart represents the condition of "pre-colonial life in Africa". At that time, African has a great nature, and culture. The African ways of life are farming and keeping the cattle. They also have their own belief, such as "funeral ceremony, harvest", etc. Besides, the people are in peaceful condition. This can be seen that they often do the ceremonies together while playing music using instruments made from "materials in the surrounding environment". In addition, this also describes that Africa has a great resource.

\section{B. What are lost/ negative effects as a result of colonial contact?}

In my opinion, the things lost due to colonial contact are "religious practice (close related to tradition) and government". This occurs because the colonizer, in this novel, "The white man" comes with a new religion and government (court/ judgement). The people gradually join the religion and the followers get protection from the place of judgement. By this way, automatically they lost their religious practice and rule little by little. It can be seen in the novel:

"But stories were already gaining ground that the white man had not only brought a religion but also a government. It was said that they had 
built "a place of judgment in Umuofia to protect the followers of their religion". It was even said that they had "hanged one man who killed a missionary".(p.109) and "seeing that the new religion welcomed twins and such abominations, thought that it was possible that they would also be received. And so one Sunday two of them went into the church. There was an immediate stir, but so great was the work the new religion had done among the converts that they did not immediately leave the church when the outcasts came in" (p.110).

Another part of the novel also mentions "But apart from the church, the white men had also brought a government. They had built a court where the "District Commissioner judged cases in ignorance". He had court messengers who brought men to him for trial. Many of these messengers came from Umuru on the bank of the Great River, where the white men first came many years before and where they had built the centre of their religion and trade and government (p.120)

The other part of the novel tells

"It is already too late," said Obierika sadly. "Our own men and our sons have joined the ranks of the stranger. They have joined his religion and they help to uphold his government. If we should try to drive out the white men in Umuofia we should find it easy. There are only two of them. But what of our own people who are following their way and have been given power? They would go to Umuru and bring the soldiers, and we would be like Abame." He paused for a long time and then said: "I told you on my last visit to Mbanta how they hanged

Aneto."_The white man is very clever. He came quietly and peaceably with his religion. We were amused at his foolishness and allowed him to stay. "Now he has won our brothers, and our clan can no longer act like one". He has put a knife on the things that held us together and "we have fallen apart."(pp.121-122)

The above story indicates that, in the case of religious practices, many people join new religion brought by 'strangers'. This of course causes the old tradition beliefs will gradually lose. Then, the strangers also build 'a court' in government i.e. used to protect the followers. By this way, the people who feel the good effects brougt by strangers, will follow the rule made by foreigners. Eventually, this makes the old rule change.

The lost of the "religious practice and government" is also described in The World Book of Encyclopaedia" The colonial period also witnessed social transformations that included changes in the patterns of urbanization, education, and religious practice. New urban centers emerged, and many old cities expanded. In these cities, Africans created 
new forms of social life and leisure activities. Many Africans educated by missionaries opposed colonialism and demanded higher education" (Anderson et al., 2007: pp.134$135)$.

\section{What are the colonizers" strategies in "indoctrinating the native population" to their way of thinking?}

The strategies used by the colonizers to persuade the native population to accept their ideas or belief are:

1. Building a "school and hospital" and going from one family to another to send their children there. This is stated in the novel "And so he built a school and a little hospital in Umuofia”, " He went from family to family begging people to send their children to his school." (p.125)

2. Convincing the society of the importance of education for the future generation. This can be found in the novel on page 125 as mentioned below.

"But at first they only sent their slaves or sometimes their lazy children. Mr. Brown begged and argued and prophesied. He said that "the leaders of the land" in the future would be men and women who had learned to read and write. "If Umuofia failed to send her children to the school, strangers would come from other places to rule them." and "In the end Mr. Brown's arguments began to have an effect. More people came to learn in his school, and he encouraged them with "gifts of singlets and towels". They were not all young, these people who came to learn. Some of them were thirty years old or more. They worked on their "farms" in the morning and went to "school" in the afternoon. (p.125)

The discussion of point ' $a$ ' and ' $b$ ' focuses on the way of thinking of the importance of education and for "a better generation" which gives the impact to a government. This can be seen in The World Book of Encyclopaedia "During the colonial period, "European settlers established schools", but the schools served only their own children and those a handful of important local leaders. Some of these reasons, about two thirds of the people who can read or write. The "literacy rate" (percentage of people who can read and write) is much lower in rural areas than that in the cities and much lower among women than among men. "The nations of northern Africa" are working to improve education, especially in rural areas. However, "the population is growing faster than new schools that can be built, and costs of education are constantly increasing". Many areas have a shortage of "qualified teachers", and many students must "leave school to work and help support their families". 
Rural children often have to travel great distances to attend school. More students however, are going on to high school and college." (Anderson et al., 2007: p.109)

3. Building the court for judgement and protection. '...they had built a place of judgment in Umuofia to protect the followers of their religion"(p.109). By this way, people will think the "function of "court' for judgement" i.e. to protect themselves from any treatment or danger.

\section{What are "positive effects as a result of colonialism"?}

The discussion on strategies used by the colonizers to indoctrinate the native population to their way of thinking above also shows that there are "positive effects of colonialism". The native population gets some benefits, they are (a) they become literate as a result of education held by the colonizers, (b) they get the health service i.e. in a hospital, (c) they get protection from "the court built by the colonizers", and (d) their economy grows due to "mutual benefit trading" as explained in reasons for colonizers' success below, in point one.

\section{E. Why are the colonizers so successful?}

There are some reasons why the colonizers are successful:

Firstly, the colonizers make "mutual benefit of trading". This is clearly stated in the novel

"The white man had indeed brought a lunatic religion, but he had also built a trading store and for the first time palm-oil and kernel became things of great price, and much money flowed into Umuofia" (p.123).

By this way, the white man get success. The native population think that they will get "advantage from the mutual benefit trading" offered by him and finally they are wealthy. This condition is also described in the World Book of Encyclopaedia that "At independence, most African economies were underdeveloped". Then "In the 1960's and 1970's, various African countries pursued different development strategies. Some opted for capitalism and free enterprise, while others pursued socialist strategies of state ownership". Most countries experienced economic growth (Anderson et al., 2007: p.135). Secondly, the colonizers use a soft way to spread the belief. For instance, when there is a problem concerning breaking "the rule of their belief" i.e. "killing a sacred pithon”, Mr. Brown comes to overcome it and make the situation calm. By this way, he is 
respected by the clan. This can be seen in the novel as stated below.

"And even in the matter of religion there was 'a growing feeling' that there might be something in it after all, something 'vaguely akin to method' in the overwhelming madness. This growing feeling was due to "Mr. Brown, the white missionary," who was very 'firm in restraining his flock from provoking the wrath of the clan'. One member in particular was very difficult to restrain. His name was "Enoch and his father was the priest of the snake cult." The story went around that "Enoch had killed and eaten the sacred python", and that "his father had cursed him". Then "Mr. Brown preached against such 'excess of zeal'. "Everything was possible, he told his 'energetic flock, but everything was not expedient". And so "Mr. Brown came to be respected even by the clan, because he trod softly on its faith" (p.123)

Thirdly, the colonizers use an innovative way to "link the religion and the education". Atfer building a school and being successful in attracting people to school, a place for religion is built. By this way, the education indirectly has a "role of promoting the religion". This can be seen in the novel "New churches were established in the surrounding villages and a few schools with them. From the very beginning religion and education went hand in hand. Mr. "Brown's mission grew from strength to strength, and because of its link with the new administration it earned a new social prestige" (p.125). This explanation also represents the "condition of Africa after independence", especially in the case of "economic life and a good government" as described below.

\section{F. Things related to the events in "the third world"}

There are some different situations experienced by Africa after colonialism, they are:

\section{(1) Religious practice}

In the case of religious practice, after colonialism, Africa tends to undergo mixed reaction. Some of the native populations keep the indigenous religion, but many of them "converts to Islam and Christianity". Many scholars call this a "triple heritage". (Olupona. Retrived February 12, 2017, from https://blog.oup.com/2014/05/15-facts-onafrican-religions/).

With the existence of traditional religion, Islam, and Christianity now, it definitely shows that Africa experiences mixed reaction in "religious practice". This depicts that the situation is different from that of before (the belief of a "supreme god, lesser gods, and the spirits of dead ancestors" when appealing something). 


\section{(2) Education}

In the matter of education as a result of colonialism, it plays an important role to get "success in a career". Students who get a good education are able to "establish success with a career for their future". On the contrary, those that do not receive the same education get difficulties even after graduation with "reading, writing, and doing math" ( https://en.wikipedia.org/wiki/Education_in_Africa). This indicates the importance of "education to achieve a good career for the future".

The above explanation on education indirectly tells us that there is a change in society's way of life, especially in the case of career. Formerly, the native populations relied on farming and keeping the cattle to make a living. Then, the later phenomenon, after colonialism, it is the education that becomes the key to get success in their career.

In addition, for women, there is also a promotion in the gender quality, more specifically in the case of education that results in work. Before the colonialism, African women stayed at home to care their families. However, after the colonialism, it is reported that there is a goal to eliminate gender discrimination and it is targeted that in primary and secondary registration if possible by 2005, and at all levels by 2015 (https://en.wikipedia.org/wiki/Education_in_Africa.) The equality in education for women certainly gives them a chance to have social and economic benefits for society. (http://www.unfpa.org/swp/2005/presskit/factsheets/facts_gender.htm)

\section{(3) Health Treatments}

To cure or prevent any disease, the African has two ways: (a) many of them keep the "traditional African healers" i.e. using ritual and herbal remedies to treat the sick people and (b) some of them go to modern cures, hospital which provides basic services, like blood transfusions needed for children who suffer from malaria-induced anaemia (http://www.our-africa.org/health). The existence of "hospital built by the colonizer" certainly contributes a new way in health treatments. The modern cures are really different from traditional treatments. The traditional treatments mostly use plants taken from the surrounding environment as mentioned in the novel:

Ezinma lay shivering on a mat beside a huge fire that her mother

had kept burning all night.

"It is iba," said Okonkwo as he took his machete and went into the

bush to collect the leaves and grasses and barks of trees that went into making the medicine for iba. (p. 53) 


\section{(4) Government/ court}

In line with justice, after colonialism, there are many States (it is said that there are 30 States in March 2016) of Africa accept "Court's jurisdiction". The States of the African Union have agreed to establish "Courts of Justice and Human Rights" which are intended to resolve disputes arising under all African Union instruments, including the "human rights, and to prosecute individuals for serious international crimes" (http://www.ijrcenter.org/regional/african/). This kind of justice contrasts with that of in the previous culture (e.g. those who "commit a crime are thrown away from the country for years"). Furthermore, this kind of punishmnet is often regarded as an "offense to goddess" as exemplified in part of the novel below.

The only "course open to Okonkwo was to flee from the clan". It was a crime against the earth goddess to kill a clansman, and a man who "committed it must flee from the land". The crime was of two kinds, male and female. Okonkwo had committed the female, because it had been inadvertent. He could return to the clan after seven years.(p.89)

Obierika was a man who thought about things. When the "will of the goddess" had been done, he sat down in his obi and "mourned his friend's calamity". Why should a man "suffer so grievously for an offence he had committed inadvertently?" But although he thought for a long time he found no answer. He was merely led into greater complexities. He remembered his wife's twin children, whom he had thrown away. What crime had they committed? The "Earth had decreed that they were an offence on the land and must be destroyed". And if the clan did not "exact punishment for an offence against the great goddess", her wrath was loosed on all the land and not just on the offender. As the elders said, "if one finger brought oil it soiled the

others". (p.89)

The condition of Africa told above adds the progress of African thoughts in accordance with the novel. The changes or progress of social life that happen in Africa come as a result of the school existence which also takes part in the "changes of African ways of thinking".

\section{CONCLUSION}

Based on the above discussion, we can draw a conclusion that Chinua Achebe shows the social condition of African before the colonial and during the colonial period 
in the novel Things Fall apart. These times remark the changes in the society. The changes can be seen through the "religious practice", such as "sacrifice in some ceremonies" etc. to a new religion. Besides, the change also can be seen in the economic that the people get wealthier from the trade with the colonizer. Furthermore, the people are more educated than before since they go to schools. By this way, the "future generation or the nation" automatically will be better. In addition, Achebe presents the lost or negative impact of the colonialism. The negative effects are on "the religion related to tradition and on the government". With the new religion, the people start to leave the old one, eventually the little by little the African lose their identity. And, in the government, there is a new form of social life - there is "a court, a new rule". By this way, the old rule is not respected anymore. Furthermore, Achebe depicts the ways used by the colonizers so that they are successful: firstly, the colonizers make "mutual benefit of trading", secondly, the colonizers use a soft way to spread the religion, and thirdly, the colonizers use an innovative way - to link "the religion and the education". Finally, after colonialism, many of the native populations "convert to other religions (Islam and Christian)", education plays the important role to get "success in career", two kinds of disease treatments (a. "the traditional African healers" i.e. using ritual and herbal remedies and b. "modern cures, hospital"), and the "establishment of Courts of Justice and Human Rights".

\section{REFERENCES}

Achebe, C. 1959. Things Fall Apart.

Anderson, M. A., Fontana, L., Taylor, S.W., and Waugh S. L. 2007. The World Book Encyclopedia. USA: World Book, Inc.

Endraswara, S.2003. Metodologi Penelitian Sastra. Yogyakarta: Pustaka Widyatama

"Gender Equality Factsheet: State of World Population 2005 - UNFPA." UNFPA - United Nations Population Fund. Web. 26 Oct. 2011. Retrieved February 12, 2017, from http://www.unfpa.org/swp/2005/presskit/factsheets/facts_gender.htm

Olupona, J. K. African Religions: A Very Short Introduction. Retrieved February 12, 2017, from https://blog.oup.com/2014/05/15-facts-on-african-religions/

Ratna, N. K.2005. Sastra dan Cultural Studies: Representasi Fiksi dan Fakta. Yogyakarta: Pustaka pelajar 
"Sub-Saharan Africa Strengthens Advocacy for Quality Education." Africa News Service 10 June 2011. Opposing Viewpoints In Context. Web. 19 July. 2013. Retrieved February 12, 2017 https://en.wikipedia.org/wiki/Education_in_Africa

"United Nations (2000), Millennium Declaration, New York: United Nations". Retrieved February 12, 2017 https://en.wikipedia.org/wiki/Education_in_Africa

http://www.our-africa.org/health Retrieved February 12, 2017.

http://www.ijrcenter.org/regional/african/. Retrieved February 12, 2017 